RFP-2245

September 13, 1974

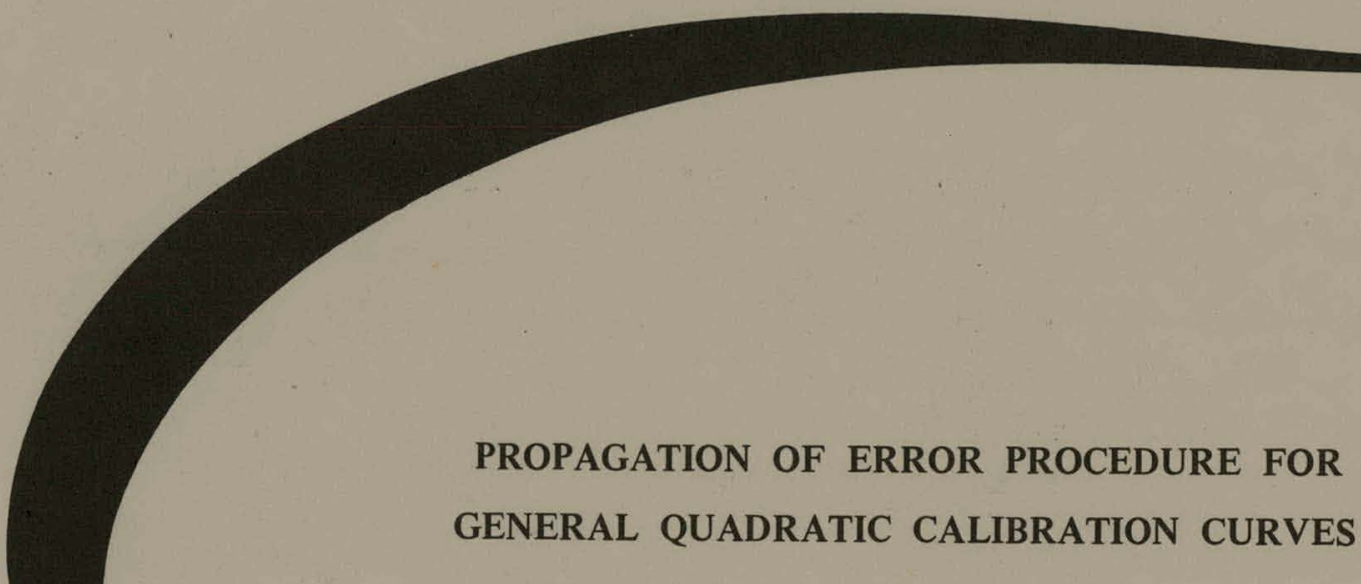

Yvonne M. Ferris

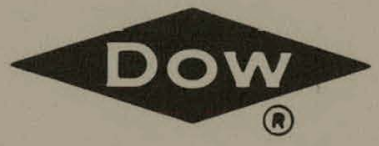

DOW CHEMICAL U.S.A. ROCKY FLATS DIVISION

P. O. BOX 888

GOLDEN, COLORADO 80401

U. S. ATOMIC ENERGY COMMISSION

CONTRACT AT(29-1)-1106 


\section{DISCLAIMER}

This report was prepared as an account of work sponsored by an agency of the United States Government. Neither the United States Government nor any agency Thereof, nor any of their employees, makes any warranty, express or implied, or assumes any legal liability or responsibility for the accuracy, completeness, or usefulness of any information, apparatus, product, or process disclosed, or represents that its use would not infringe privately owned rights. Reference herein to any specific commercial product, process, or service by trade name, trademark, manufacturer, or otherwise does not necessarily constitute or imply its endorsement, recommendation, or favoring by the United States Government or any agency thereof. The views and opinions of authors expressed herein do not necessarily state or reflect those of the United States Government or any agency thereof. 


\section{DISCLAIMER}

Portions of this document may be illegible in electronic image products. Images are produced from the best available original document. 


\section{LEGAL NOTICE}

This report was prepared as an account of work sponsored by the United States Government. Neither the United States nor the United States Atomic Energy Commission, nor any of their employees, nor any of their contractors, subcontractors, or their employees, makes any warranty, expressed or implied, or assumes any legal liability or responsibility for the accuracy, completeness or usefulness of any information, apparatus, product or process disclosed, or represents that its use would not infringe privately owned rights.

Printed in the United States of America

Available from the

National Technical Information Service

U. S. Department of Commerce

Springfield, Virginia 22151

Price: Printed Copy $\$ 4.00$ Microfiche $\$ 1.45$ 
Printed

September 13, 1974
RFP-2245

UC-32 MATHEMATICS AND COMPUTERS

TID-4500-R60

\title{
PROPAGATION OF ERROR PROCEDURE FOR GENERAL QUADRATIC CALIBRATION CURVES
}

\author{
Yvonne M. Ferris
}

Production Control and Nuclear Materials Management STATISTICAL LABORATORY GROUP

\begin{abstract}
This report was prepared as an account of work sponsored by the United States Gnvernment. Neither the United States nor the United States Atomic Energy inmmission. nor any of their cmployees, nor any of their contractors, subcontractors, or their employees, makes any warranty, express or implied, or assumes any legal liability or responsibility for the accuracy, completeness or uscfulness of any information, apparatus product or process disclosed, or represents that its use would not infringe privately owned rights.
\end{abstract}

SUBJECT DESCRIPTORS

Statistics

Least Squares

Regression

Propagation of Error

DOW CHEMICAL U.S.A. ROCKY FLATS DIVISION

P. O. BOX 888

GOLDEN, COLORADO 80401

Prepared under Contract AT(29-1)-1106

for the

Albuquerque Operatinns Office

U. S. Atomic Energy Commission 
RFP-2245 


\section{CONTENTS}

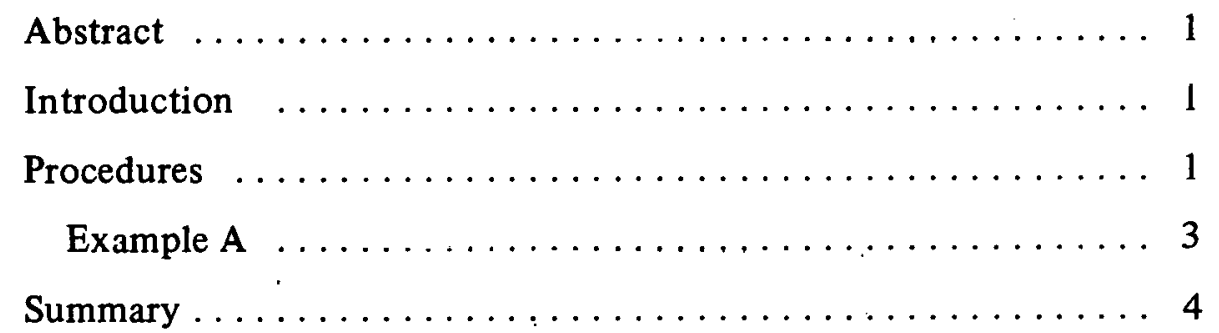


RFP-2245 


\title{
PROPAGATION OF ERROR PROCEDURE FOR GENERAL QUADRATIC CALIBRATION CURVES
}

\author{
Yvonne M. Ferris
}

\begin{abstract}
Establishing a calibration curve consists of determining a mathematical relationship between a known quantity and a measured response. When solved in reverse, such a mathematical function becomes the calibration curve. If the calibration line is the solution of a straight line, the standard deviation of a quantity determined from the function can be easily obtained. If the calibration line is the solution of a quadratic, propagating the errors associated with a quantity determined from the line becomes a difficult and error-prone algebraic exercise. The problems become more troublesome, if the increments of calibration are not equal. Given is a procedure for calculating the standard deviation of a quantity determined from the least squares fit of a quadratic equation solved in reverse.
\end{abstract}

\section{INTRODUCTION}

The object of calibration is to provide a mathematical function relating a known input quantity to an output measurement reading. The function can then be used in reverse with a measurement reading determining a stated amount.

For the best results, equipment should be designed such that its calibration produces a straight line. If this is not possible, effort should be made to use the equipment in a narrow range, such that departures from linearity are negligible. If linear calibration cannot be employed, a curvilinear function must be developed. Such a function could take almost any form such as exponential, power, or polynomial. Nll of these can be transformed into a linear form and least squares used to calculate the coefficients.

The function applicable to many curvilinear situations is a quadratic of the form:

$$
Y=a+b_{1} x+b_{2} x^{2}
$$

Where:

$$
\begin{aligned}
& \mathrm{Y}=\text { measured response } \\
& \mathrm{X}=\text { known input quantity }
\end{aligned}
$$

While computers easily calculate the coefficients and associated standard deviations of this expression, the use of the information is complicated at best. Solving a quadratic equation in reverse, i.e., for $X$ given $Y$, results in a tedious and error-prone exercise.

The solution and propagated errors of Equation 1 for the case of equal increments have been detailed in Statistical Methods in Nuclear Material Control, Chapter 3. ${ }^{1}$ For the general case where the increment is not equal for the full range of the calibration, the technique herein described must be used. All of the covariance effects are present resulting in a long and complex expression. The statistics are developed in Equations 2 through 13 followed by an example.

\section{PROCEDURES}

Using matrix notation and assuming independent random errors associated with the measurement values, the coefficients and their standard deviations are:

$$
\begin{aligned}
b & =\left(X^{\prime} X\right)^{-1}\left(X^{\prime} Y\right) \\
V(b) & =\left(X^{\prime} X\right)^{-1}(\sigma)^{2}
\end{aligned}
$$

Where:

$$
\begin{array}{r}
b=\text { least squares estimate of the } \\
\text { coefficients in Equation } 1
\end{array}
$$

$$
b_{0}=\text { the same as "a" in Equation } 1
$$

\footnotetext{
'John L. Jaech. Statistical Methods in Nuclear Material Control. Chapter 3. TID 26298. Tecluical Information Centcr, U. S. A tomic Energy Commission, Government Printing Office, Washington, D.C. December 1973.
} 
RFP-2245
$V(b)=$ variance of coefficients
$\mathrm{X}=$ the $\mathrm{n}-\mathrm{by}-3$ matrix of the independent variables
$(\sigma)^{2}=$ variance about regression
$\mathrm{Y}=$ vector of the measured response
$\mathbf{X}^{\prime}=$ transpose of the $\mathrm{X}$ matrix

The off-diagonal members of the variance matrix are the covariances.

The solution to Equation 1 for $\mathrm{x}$ given $\mathrm{Y}$ is:

$$
x= \pm \sqrt{\frac{Y-a}{b_{2}}+\left(\frac{b_{1}}{2 b_{2}}\right)^{2}}-\frac{b_{1}}{2 b_{2}}
$$

The variance of $x$ is determined by propagating the errors associated with $a, b_{1}, b_{2}$, and $Y$. Thus, the variance is:

$$
\begin{aligned}
\mathrm{s}_{\mathrm{X}}^{2}= & \left(\frac{\partial \mathrm{x}}{a_{\mathrm{a}}}\right)^{2} \mathrm{~s}_{\mathrm{a}}^{2}+\left(\frac{\partial \mathrm{x}}{\partial \mathrm{b}_{\mathrm{i}}}\right)^{2} \mathrm{~s}_{\mathrm{b}_{1}}^{2}+\left(\frac{\partial \mathrm{x}}{\partial \mathrm{b}_{2}}\right)^{2} \mathrm{~s}_{\mathrm{b}_{2}}^{2}+2 \operatorname{cov}\left(\mathrm{a}, \mathrm{b}_{1}\right)\left(\frac{\partial \mathrm{x}}{\partial \mathrm{a}}\right)\left(\frac{\partial \mathrm{x}}{\partial \mathrm{b}_{1}}\right) \\
& +2 \operatorname{cov}\left(\mathrm{a}, \mathrm{b}_{2}\right)\left(\frac{\partial \mathrm{x}}{\partial \mathrm{a}}\right)\left(\frac{\partial \mathrm{x}}{\partial \mathrm{b}_{2}}\right)+2 \operatorname{cov}\left(\mathrm{b}_{1}, \mathrm{~b}_{2}\right)\left(\frac{\partial \mathrm{x}}{\partial \mathrm{b}_{1}}\right)\left(\frac{\partial \mathrm{x}}{\partial \mathrm{b}_{2}}\right)+\left(\frac{\partial \mathrm{x}}{\partial \mathrm{Y}}\right)^{2} \mathrm{~s}_{\mathrm{Y}}^{2}
\end{aligned}
$$

The partial derivatives are as follows, where $x_{1}$ is the positive radical and $x_{2}$ is the negative radical of Equation 4:

$$
\text { I.et } \begin{aligned}
k=\sqrt{\frac{Y-a}{b_{2}}+\left(\frac{b_{1}}{2 b_{2}}\right)^{2}} \\
\frac{\partial x_{1}}{\partial a}=\frac{-1}{2 b_{2} k} \\
\frac{\partial x_{2}}{\partial a}=\frac{1}{2 b_{2} k} \\
\frac{\partial x_{1}}{\partial b_{1}}=\frac{b_{1}}{\left(2 b_{2}\right)^{2} k}-\frac{1}{2 b_{2}} \\
\frac{\partial x_{2}}{\partial b_{1}}=\frac{-b_{1}}{\left(2 b_{2}\right)^{2} k}-\frac{1}{2 b_{2}}
\end{aligned}
$$




$$
\begin{aligned}
& \frac{\partial x_{1}}{\partial b_{2}}=-\frac{\left[\frac{Y-a}{\left(b_{2}\right)^{2}}+\frac{b_{1}^{2}}{2\left(b_{2}\right)^{3}}\right]}{2 k}-\frac{b_{1}}{2\left(b_{2}\right)^{2}} \quad \text { (10) } \frac{\partial x_{2}}{\partial b_{2}}=\frac{\left[\frac{Y-a}{\left(b_{2}\right)^{2}}+\frac{b_{1}^{2}}{2\left(b_{2}\right)^{3}}\right]}{2 k}+\frac{b_{1}}{2\left(b_{2}\right)^{2}} \\
& \frac{\partial x_{1}}{\partial Y}=\frac{1}{2 b_{2} k}
\end{aligned}
$$

\section{Example A:}

An example is taken from Jaech. ${ }^{2}$ A calibration data set consists of measurement readings (Y) for a known

\begin{tabular}{|c|c|c|}
\hline $\mathrm{x}_{\mathrm{i}}$ & & $\mathrm{Y}_{\mathrm{i}}$ \\
\hline$\overline{20}$ & & 595 \\
\hline 30 & & 867 \\
\hline 40 & & 1180 \\
\hline 50 & & 1389 \\
\hline 60 & - & 1627 \\
\hline 70 & & 1813 \\
\hline 80 & & 2093 \\
\hline
\end{tabular}
standard ( $\mathrm{x})$ :

The equipment design is such that a quadratic best fits the data and has the form: $Y=a+b_{1} x+b_{2} x^{2}$.

The inverse of the $\left(\mathrm{X}^{\prime} \mathrm{X}\right)$ matrix is:

$\left(X^{\prime} X\right)^{-1}=\left[\begin{array}{rrr}7 & 350 & 20,300 \\ 350 & 20,300 & 1,295,000 \\ 20,300 & 1 ; 295,000 & 87,710,000\end{array}\right]^{-1}=\left[\begin{array}{lll}6.285714 & -0.2678571 & 0.0025 \\ -0.2678571 & 0.0122619 & -1.190476 \times 10^{-4} \\ 0.0025 & -1.190476 \times 10^{-4} & 1.190476 \times 10^{-6}\end{array}\right]$.

The coefficients, their standard deviations and covariances are:
$\mathrm{a}=1.85714$
$\mathrm{s}_{\mathrm{a}}=80.23256$
$b_{1}=30.79643$
$\mathrm{s}_{\mathrm{b}_{1}}=3.543662$
$s_{Y}=32.00173$
$\mathrm{b}_{2}=-0.063929$
$\mathrm{s}_{\mathrm{b}_{2}}=0.034 .917$
$\operatorname{cov}\left(\mathrm{a}, \mathrm{b}_{1}\right)=-274.315328$
$\operatorname{cov}\left(\mathrm{a}, \mathrm{b}_{2}\right)=\quad 2.560277$
$\operatorname{cov}\left(b_{1}, b_{2}\right)=-0.12191792$

The question now becomes, what is the value and the standard deviation of $\mathrm{x}$ for a given measurement of $\mathrm{Y}$, as $Y=1000$. The solution of Equation 4 for $Y=1000$ is:

$$
\mathrm{x}_{1}=447.16 \text { (Positive Radical) } \quad \mathrm{x}_{2}=34.57 \text { (Negative Radical) }
$$


RFP-2245

Clearly, $x_{2}$ is the solution in question. To find the estimate of the variance of $x_{2}=34.57$. then, Equations $7,9,11$, and 13 , as well as the covariance effects must be calculated. They are as follows:

$$
\begin{aligned}
& \text { Let } \mathrm{k}=\sqrt{\frac{1000-11.85714}{-0.063929}+\left[\frac{30.79643}{2(-0.063929)}\right]^{2}} \\
& \left(\frac{\partial \mathrm{x}_{2}}{\partial \mathrm{a}}\right)^{2} \mathrm{~s}_{\mathrm{a}}^{2}=\left[\frac{1}{2(-0.063929) \mathrm{k}}\right]^{2}(80.23256)^{2}=9.25245 \\
& \left(\frac{\partial \mathrm{x}_{2}}{\partial \mathrm{b}_{1}}\right)^{2} \mathrm{~s}_{\mathrm{b}_{1}}^{2}=\left\{\frac{-30.79643}{[2(-0.063929)]^{2} \mathrm{k}}-\frac{1}{2(-0.063929)}\right\}^{2}(3.54366)^{2}=21.56621 \\
& \left(\frac{\partial x_{2}}{\partial b_{2}}\right)^{2} s_{b_{2}}^{2}=\left[\frac{\frac{1000-11.85714}{(-0.063929)^{2}}+\frac{(30.79643)^{2}}{2(-0.063929)^{3}}}{2 k}+\frac{30.79643}{2(-0.063929)^{2}}\right]^{2}(0.034917)^{2}=2.50183 \\
& 2 \operatorname{cov}\left(a, b_{1}\right)\left(\frac{\partial x_{2}}{\partial a}\right)\left(\frac{\partial x_{2}}{\partial b_{1}}\right)=-27.25790 \\
& 2 \operatorname{cov}\left(\mathrm{a}, \mathrm{b}_{2}\right)\left(\frac{\partial \mathrm{x}_{2}}{\partial \mathrm{a}}\right)\left(\frac{\partial \mathrm{x}_{2}}{\partial \mathrm{b}_{2}}\right)=8.79399 \\
& 2 \operatorname{cov}\left(b_{1}, b_{2}\right)\left(\frac{\partial x_{2}}{\partial b_{1}}\right)\left(\frac{\partial x_{2}}{\partial b_{2}}\right)=-14.47517 \\
& \left(\frac{\partial x_{2}}{\partial Y}\right)^{2} \mathrm{~s}_{Y}^{2}=\left[\frac{-1}{2(-0.063929) \mathrm{k}}\right]^{2}(32.00173)^{2}=1.47198
\end{aligned}
$$

Total variance $=9.25245+21.56621+2.50183-27.25790+8.79399-14.47517+1.4798=1.853$.

Therefore, for: $Y=1000, \mathrm{x}_{2}=34.57$, and $\mathrm{s}_{\mathrm{X}_{2}}=1.36$.

The above exercise in algebra can be reduced immensely by assuring that all the $x_{i}$ are evenly spaced and then constructing orthogonal polynomials. ${ }^{3}$ All of the covariances between the coefficients become zero.

\section{SUMMARY}

The technique presented has application in any of the calibration situations where a quadratic function adequately represents the relationship between the pertinent variables throughout the entire range of calibration.

\footnotetext{
${ }^{3}$ N. R. Draper and H. Smith. Applied Regression Analysis. John Wiley and Sons, Incorporated, New York. 1967.
} 